\title{
Preferences of German Consumers for Meat Products Blended with Plant-Based Proteins
}

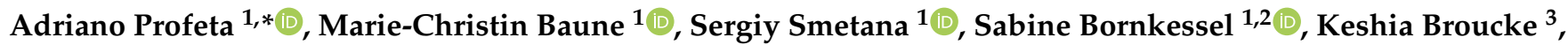 \\ Geert Van Royen ${ }^{3}{ }^{\circ}$, Ulrich Enneking ${ }^{2}$, Jochen Weiss ${ }^{4}{ }^{(}$, , Volker Heinz ${ }^{1}$, Sopie Hieke ${ }^{5}\left(\mathbb{D}\right.$ and Nino Terjung ${ }^{1}$
}

1 DIL e.V.-German Institute of Food Technology, Research Platform Consumer Science, Prof.-von-Klitzing-Straße 7, 49610 D-Quakenbrück, Germany; m.baune@dil-ev.de (M.-C.B.); s.smetana@dil-ev.de (S.S.); s.bornkessel@dil-ev.de (S.B.); v.heinz@dil-ev.de (V.H.); n.terjung@dil-ev.de (N.T.)

2 Institute of Agricultural Marketing, Applied University of Osnabrück, Albrechtstr. 30, 49076 Osnabrück, Germany; u.enneking@hs-osnabrueck.de

3 Institute for Agricultural and Fisheries Research (ILVO), Brusselsesteenweg, 370, 9090 Melle, Belgium; k.broucke@ilvo.vlaanderen.bl (K.B.); geert.vanroyen@ilvo.vlaanderen.bl (G.V.R.)

4 Departement of Food Structure and Functionality, Institut of Food Science and Biotechnology, University of Hohenheim, Garbenstraße 21/25, 70599 Stuttgart, Germany; j.weiss@uni-hohenheim.de

5 European Food Information Council, Rue des Deux Eglises 14, 1000 Brussels, Belgium; sopie.hieke@eufic.org

* Correspondence: a.profeta@dil-ev.de; Tel.: +49-5431-183-326

check for

updates

Citation: Profeta, A.; Baune, M.C.; Smetana, S.; Bornkessel, S.; Broucke, K.; Van Royen, G.; Enneking, U.; Weiss, J.; Heinz, V.; Hieke, S.; Terjung, N. Preferences of German Consumers for Meat Products Blended with Plant-Based Proteins. Sustainability 2021, 13, 650 . https: / / doi.org/10.3390/ su13020650

Received: 25 November 2020 Accepted: 7 January 2021 Published: 12 January 2021

Publisher's Note: MDPI stays neutral with regard to jurisdictional clai$\mathrm{ms}$ in published maps and institutional affiliations.

Copyright: (C) 2021 by the authors. Licensee MDPI, Basel, Switzerland. This article is an open access article distributed under the terms and conditions of the Creative Commons Attribution (CC BY) license (https:// creativecommons.org/licenses/by/ $4.0 /)$.

\begin{abstract}
High levels of meat consumption are increasingly being criticised for ethical, environmental, and social reasons. Plant-based meat substitutes have been with reservations identified as healthy sources of protein in comparison to meat. This alternative offers several social, environmental, and probably health benefits, and it may play a role in reducing meat consumption. However, there has been a lack of research on how specific meat substitute attributes can influence consumers to replace or partially replace meat in their diets. Research has demonstrated that, in many countries, consumers are highly attached to meat. They consider it to be an essential and integral element of their daily diet. For the consumers that are not interested in vegan or vegetarian alternatives to meat, so-called meathybrids could be a low-threshold option for a more sustainable food consumption behaviour. In meathybrids, only a fraction of the meat product (e.g., 20\% to 50\%) is replaced with plant-based proteins. In this paper, the results of an online survey with 500 German consumers are presented with a focus on preferences and attitudes relating to meathyrids. The results show that more than fifty percent of consumers substitute meat at least occasionally. Thus, approximately half of the respondents reveal an eligible consumption behaviour with respect to sustainability and healthiness to a certain degree. Regarding the determinants of choosing either meathybrid or meat, it becomes evident that the highest effect is exerted by the health perception. The healthier meathybrids are perceived, the higher is the choice probability. Thus, this egoistic motive seems to outperform altruistic motives, like animal welfare or environmental concerns, when it comes to choice for this new product category.
\end{abstract}

Keywords: meat substitute; meathybrid; consumer preference; plant-based proteins

\section{Introduction}

There are more than 7.7 billion people on this planet, with forecasts predicting the population to grow to 9.7 billion by 2050 [1]. Therefore, securing a sustainable food supply for humankind is becoming a major challenge. Diets with a high share of animal proteins must be adapted in order to ensure that demand is not outstripping production $[2,3]$. Furthermore, the consumption of meat and meat products in larger portions is associated with higher risks on prevalence of cardiovascular, coronary and cerebrovascular diseases, stroke, diabetes type 2 and colorectal cancer [4].

In addition to these health issues, meat production chains have a considerable impact on the environment through the use of land, application of fertilisers, greenhouse emis- 
sions, and water consumption, resulting in a loss of biodiversity and enhancing climate change [5-8]. The environmental burden of animal protein production varies by animal type [9] and the livestock system used [10]. Despite this variance, there is agreement that a reduction in the consumption of animal-based proteins would be beneficial for biodiversity, land and water use, as well as the climate [11]. A recent study of Xue et al. [12] demonstrates that the substitution of meat with plant-proteins by $50 \%$ can reduce greenhouse gas emissions by $32 \%$. Own calculations based on the Agri-Footprint database [13] show that the incorporation of plant biomass into pork products in equal proportion can likewise lead to a reduction of their environmental impact.

A variety of options is currently available for achieving a partial substitution of animalbased proteins by plant proteins. However, it should be noted that many conventional Western meat-free dishes contain other animal-based products such as fish, eggs, cheese or other dairy products. From a sustainability perspective, these products offer not much advantage when compared with meat [14].

It is worth highlighting that meat and meat products are also associated with severe animal welfare issues, such as pigtail docking, poultry debeaking, calves separation and the mistreatment in slaughterhouses $[15,16]$. Furthermore, diversity in eating habits is getting lost because developing countries adopt a more animal-rich, western style diet. In this context, Sans and Combris [17] stated that humankind is heading for a generalisation of its diet through animal proteins.

All of these facts underline the importance of integrating new protein sources into the diet. However, this means overcoming barriers, such as traditional meat consumption, across many cultures [18]. To this effect, a promising alternative pathway is to increase the share of plant proteins in the diet. This could be done by using, e.g., textured soy protein and pulses etc. as a complete substitute for animal-protein. Another opportunity is to replace only a fraction of the meat product (e.g., 20\% to 50\%) with plant-based proteins [19]. Research demonstrates that, in many countries, consumers are highly attached to meat and consider it to be an essential and integral element of their daily diet [20]. So-called meathybrids may be an option for the broad consumer segment that is not interested in vegan or vegetarian alternatives to meat. Therefore, meathybrids could serve as a lowthreshold offer for this group, facilitating the transition in direction to a more healthy and sustainable diet.

As with many novel technologies, consumers' lack of understanding of hybrid meat products may lead to scepticism and ultimately to the rejection of these. Through the early integration of consumer demand and preferences into the development process, more suitable hybrid products can be designed. Understanding the decision-making process will help to develop tailored communication messages that highlight its benefits as a sustainable and healthy alternative to regular meat products.

The study aims at identifying consumer attitudes and preferences for meat alternatives, such as meathybrids. Based on a literature overview, a representative online-survey was carried out in Germany.

\section{Literature Overview about Consumer Attitudes and Preferences Relating to Meat and Meat Alternatives}

The literature analysis focuses on the time period 2010-2020 for presenting the status quo of knowledge regarding consumer demand for meat and meat alternatives. Elderly articles only entered the analysis if these delivered a fundamental contribution to the research. The research databases and search engines-EBSCO host, Google Scholar, Research Gate and Science Direct were selected for literature research. The following search terms were chosen: meat consumption, food choice motives+meat, food choice \& meat, meat alternatives, meat replacer, preferences \& meat consumption, attitudes \& consumption etc. Furthermore, in the found papers, a cross-check was applied in order to identify additional papers. 


\subsection{Sensory}

Concerning meat consumption, there is a consensus that consumer preferences are, in particular, affected by products' sensory characteristics. An inferior or low sensory quality can constitute a critical barrier for the market entry of meat substitutes [21,22]. Therefore, meat substitutes, respectively, meathybrids must catch up with real meat products concerning sensory characteristics. A study that was carried out by Topcu et al. [23] demonstrated that the sensory quality factors aroma $(29.6 \%)$ and visible quality $(5.3 \%)$ explained most of Turkish consumers' preferences for red meat consumption when compared to hedonic factors (e.g., product image, nutritional value, cost, meat source and durability, and the origin of the meat).

Sensory appeal is often problematic in reducing or changing meat consumption to alternatives like in vitro (cultured, lab grown, etc.) meat, eating nose-to-tail (e.g., offal, hooves, eyes etc.) or entomophagy (eating insects) [21]. The replacement of meat by plant proteins without altering sensory characteristics as well as technological properties is a major challenge. The application of plant proteins is limited, as their composition and properties highly depend on the isolation method as well as environmental factors. For example, Akwetey et al. [24] reported that only 5\% of ground beef could be replaced with whole cowpea flour in emulsion-type sausages without any negative effects on their sensory and physical-chemical properties. Zayas and Lin [25] demonstrated that the addition of $2 \%$ preswelled corn germ protein to frankfurters already changes the viscosity of the meat batter. Furthermore, an increase in off-flavour and off-aroma was observed with time in storage. Contrarily, high-moisture extrusion technology has especially advanced the production of vegan meat alternatives with high sensory acceptance in the last decade [26,27]. In addition, own research in the framework of the AIF-Meathybrid project showed that by adjustments in the type of protein and application form, the production of hybrid chicken nuggets with $>50 \%$ meat (protein) substitution was possible [28]. The substitution does not entail any technological disadvantages and from the technical point is easy to implement. However, the sensorial optimization of the products and legal situation are crucial for a successful market launch and they should be considered separately.

In this study, there was no sensory tasting, but consumers had to compare meat and meathybrids on their expected taste. To the authors, no other studies are known, where information regarding the taste expectation of meathybrid-like alternatives vs. meat were collected. Thus, this study delivers first consumer insights in this context. Furthermore, it is analysed how the taste expectation influences the choice of a meathybrid vs. a meat product.

\subsection{Environment}

Meat production causes more emissions per unit of energy when compared with that of plant-based foods, because energy is lost at each trophic level. It is the most important source of methane, which has a relatively high global warming potential, but a lower half-life in the environment as compared with that of $\mathrm{CO}_{2}$ [29]. The carbon footprint of plant-based foods, on average, is twice as low as impact of pork [30], while the impact in some other categories can be more than 60 times lower [31]. The incorporation of plant biomass into pork products in equal proportion leads to the reduction of their environmental impact.

Some studies show that the majority of Western European consumers are not aware that meat consumption has a large environmental impact [21,32,33]. Contrarily, Apostolidis and McLeay [34] stated that the ecological rationale for switching to meat alternatives is being recognised, but cannot overcome sensory shortcomings (see above). Likewise, Siegrist and Hartmann [35] found that consumers with perceptions regarding the high environmental impact of meat were more likely to consume meat substitutes when compared with people who had the opposite attribute. Concerning consumer segments, Mullee et al. [36] found that vegetarians are more likely than omnivores to agree that meat production is bad for the environment and unhealthy. 
In this study, respondents had to evaluate whether either meathybrids or meat is better for the environment. Furthermore, the impact of this evaluation/perception on the choice of a meathybrids vs. a meat products was analysed.

\subsection{Animal Welfare}

A study among Belgian consumers explored the relationship between morality and diet choice by investigating how animal and human welfare attitudes can predict a meat eating vs. flexitarian vs. vegetarian diet [37]. The results show that animal health concerns (measured via an animal attitude scale) can predict diet choice. Vegetarians are most concerned, while full-time meat eaters are least concerned. The contrast between flexitarians and vegetarians is greater than the contrast between flexitarians and full-time meat eaters [37].

Because of the lower meat content, it is to be expected that consumers consider meathybrids to be better for animal welfare in comparison to a 'pure' meat product, because less animals have to be kept and slaughtered. Nonetheless, for hybrids, animals still must die. Therefore, it is unclear whether animal welfare could be a driver for the choice of meathybrids. For analysing this question, in this study the animal welfare perception in comparison to meat is examined.

\subsection{Health}

It is known that the frequent consumption of processed meat can increase the risk of cardio vascular disease as well as all-cause mortality $[38,39]$. By contrast, a higher intake of whole grains, legumes, and nuts is associated with cardiovascular benefits, due to the intake of less saturated fatty acids and dietary cholesterol, and more soluble fibers and poly unsaturated fatty acids $[40,41]$. However, plant proteins often have an incomplete amino acid profile because certain essential amino acids are not present in sufficient quantities, e.g., sulfuric amino acids in legumes or lysin in cereals. For this reason, they must be mixed with other vegetable proteins or food that contain these amino acids in sufficient concentrations [42].

It is important to highlight that many consumers consider meat products to be an important source of nutrients and a traditional component of their diet. It is generally perceived as a healthy food [43]. Concerning gender, in the latter study women tended to be more interested in plant foods (meat is often associated with masculinity). One quarter of the respondents believed that eating vegetarian food frequently is unhealthy. More than half of semi-vegetarians did not agree that meat consumption is unhealthy per se. Like in the study of De Backer and Hudders [37], omnivores associated meat with good health and disagreed that meat production is bad for the environment. Perceived healthiness has been a positive predictor of red meat consumption. Furthermore, among omnivores and flexitarians that represent a potential target group for meathybrids, there are large consumer segments that consider meat substitutes to be unhealthy.

In this study, we analyse (see Section 4.4) whether meathybrids are still perceived as unhealthy in comparison to meat and whether this health perception has an impact on the choice of hybrids. Furthermore, the research results indicate that organic consumers have a healthier diet than other consumers $[35,44]$. This suggests that there might be a positive relationship between organic consumption and a healthy lifestyle. Therefore, it could be hypothesized that consumers with a preference for organic foods reject meathybrids. Consistently, De Boer et al. [2] found that a negative correlation between the buying frequency of organic meat and the buying frequency of meat replacer and the general preference for food with plant-based proteins. Contrarily, according to Siegrist and Hartmann [35], an organic preference goes along with a lower meat consumption and, in this context, hybrids could represent an interesting option for organic consumers. Therefore, in this study, the impact of the preference for organic food that is measured by the buying frequency of organic respectively free range meat on the choice of hybrids was analysed. 


\subsection{Meat Attachment Questionnaire (MAQ)}

Recent research put forward the idea that consumers have an affective connection towards meat that may play a role in their willingness to change consumption habits [20]. It is argued that the affection towards meat may represent a continuum, in which one end refers to disgust (i.e., negative affect and repulsion, related with moral internalization), while the other shows a pattern of attachment (i.e., high positive affect and dependence towards meat, and feelings of sadness and deprivation when considering abstaining from meat consumption) that may hinder a change in consumption habits [20]. Meat attachment mirrors the main characteristic of the general concept of attachment, which is the presence of a positive bond and desire to maintain closeness to the object of attachment.

In this study, 15 out of the 16 items of the Meat Attachment Questionnaire (MAQ) of Graca et al. [20] were selected for measuring the psychometric construct (see Table 3). One item of the original MAQ-list did not enter into the online survey because of an error.

\subsection{Food Neophobia Scale (FNS)}

Food neophobia refers to a reluctance to eat unfamiliar foods [45]. It has been the subject of many studies across many countries, and it affects the quality as well as a variety of foods in the diet [46-50]. The knowledge about population segments that have greater or lesser neophobia allows for identifying early adopters of innovative products [51].

According to Tucker [22] more elderly consumers more likely hold negative views towards in vitro meat. They saw in vitro not as real meat, not as something natural, and hence unhealthy. It is to hypothesise that possibly this finding could hold for meathybrids that are partly highly processed as well. According to Apostolidis and McLeay [34] and Siegrist and Hartmann [35] low levels of acceptance for meat substitutes have been associated with high levels of the construct food neophobia. In this study, the food neophobia scale (FNS) of Pliner and Hobden [45] was selected for measuring the psychometric construct (see Table 4) and analysing its impact on the choice of a hybrid alternative. Because meathybrids are relatively new products on the market, we expect that especially food neophobia acts as a barrier on the first trial with hybrids.

\subsection{Product Familiarity Meat Substitutes}

According to Hoek et al. [52] unfamiliarity with meat substitutes is a key barrier for non-users and light/medium-users. Similarly, Schosler et al. [14] found that a lack of familiarity hampers a change to real vegetarian meals. In this study, consumers are asked for their previous consumption of meat substitutes and the impact of product familiarity on the choice of hybrids is analysed.

\section{Material and Methods}

\subsection{Data Collection}

Consumer data were collected using a quantitative online survey approach. The respondents have been recruited by the market research company Savanta (London, UK). The questionnaire comprised questions about the general meat consumption on the one hand and specific questions concerning preferences for meat substitutes on the other hand (see questionnaire in the Supplementary Materials). In this paper not all, but selected parts of the survey are reported.

The online survey was carried out in Germany with 500 respondents (see Appendix A). The participants had to be meat eaters and thus vegetarians and vegans were sorted out. Furthermore, the participants had to be mainly, respectively, 50\% responsible for food shopping in the household. Data collection took place in the time period from 8 November until 19 November 2019 (see Table A1). 


\subsection{Preferred Buying Location and Buying Frequency of Organic Respectively Free Range Meat}

In the beginning of the questionnaire, the consumers were asked about their preferred buying location of meat and meat products and their buying frequency of organic free range meat. For the preferred buying location, several options were indicated (retailer, discount, butcher, (farmer) market, online, farm, others). A single-item measure was used in order to obtain information regarding the degree to which one's household buys organic or free range meat. The answer categories were "never", "sometimes", "often", and "always" [2].

\subsection{Applied Scales-FNS and MAQ}

For scale development (FNS, MAQ) Cronbach's alpha is calculated and reported. For MAQ, the participants answered on a five-point response scale [20] that was verbally and numerically anchored $(1=$ strongly disagree, $2=$ disagree, $3=$ neither disagree nor agree, $4=$ agree, $5=$ strongly agree). The items indicated with ( $\mathrm{r}$ ) in Table 3 were inversely re-coded.When considering that the inclusion of invalid items creates the risk of invalid conclusions [53], a principal component analysis (Varimax rotation, eigenvalues greater than one) and a confirmatory factor analysis were carried out in order to explain the variability of the MAQ.

For measuring FNS, the list of Pliner and Hobden [45] was selected (see Table 4). The wording of the German version has been chosen from a study by [35]. The participants answered on a five-point response scale that verbally and numerically anchored $(1=$ totally disagree, 2 = disagree, $3=$ neither disagree nor agree, $4=$ agree, and $5=$ totally agree). The five-point scale was used instead of the originally used seven-point scale for a better display of the questionnaire on tablets and smartphones. The items indicated with $(r)$ were inversely re-coded. Like for the MAQ, a principal component analysis and confirmatory factor analysis were carried out.

\subsection{Direct Questions about the Consumption of Meat Substitutes}

The survey questionnaire comprehended several direct questions regarding the consumption of meat substitutes. In this context, the respondents were asked: "On the days you don't eat meat, do you deliberately substitute something for it?". The answers were "yes" and "no". Subsequently, this group had to indicate with which products they concretely substitute meat. The question was "With what do you substitute it?". Following the approach of De Boer et al. [2], for this purpose they received a list of twelve products (see Table 5) from where up to three products could be chosen. In this list, some substitutes were inserted that are non-protein foods and, thus, cannot be considered to be a meat substitute from a nutritional point of view. Nonetheless, according to Montanari [54], pasta dishes have slightly neutralized the role of meat as a centrepiece on the plate, such as in the Mediterranean diet. Consumers do not think in terms of proteins when it comes to meat substitutes. According to Biesbroek et al. [55], substitution components, like potatoes, total vegetables, pasta, rice, and couscous, can replace meat in a hot meal.

Additionally, a single-item measure was used in order to obtain information regarding the degree to which one's household buys meat replacers, such as veggie burgers. The answer categories were "never", "tried once", "rarely", "sometimes", and "frequently". The question was "how often do you buy meat replacers, such as veggie burgers?".

\subsection{Comparison Task Meathybrid vs. Meat}

In order to analyse the preference for meathybrids in more detail, the respondents received a comparison task. The question for this task was: "Consider a food product made of $100 \%$ meat (product A) and a comparable food product made of $60 \%$ meat and $40 \%$ plant-based proteins (product B). Which product do you think is ...

- healthier?

- tastier?

- better for the environment?

- better for animal welfare? 
Furthermore, the respondents had to decide whether they would choose either the introduced meathybrid with $40 \%$ plant-based proteins or the corresponding meat product if they had to do so. The question was: "Which product would you choose?" The answer options were "product A", "product B", "neither nor".

\subsection{Logistic Regression Analysis}

Via a multinomial regression analysis (see Appendix B for a theoretical background), it was explored whether the MAQ and the FNS have an impact on the last mentioned choice decision in the questionnaire. In the choice task of the comparison (see Section 3.5), the respondents were asked directly whether they would either choose the meat or the hybrid product or none of these products. This variable was chosen as a dependent variable for the logistic regression model.

Furthermore, the parameters from the direct comparison (health, taste, environment, animal welfare) between meat and hybrid entered into the regression as independent variables as well as the buying frequency of organic/free range meat and the buying frequency of plant-based alternatives (like veggie burger) and the mentioned MAQ- and FNS-scale.

The parameters from the direct comparison were re-coded, so that +1 reflects the choice of the hybrid (e.g., as more healthy, better for the environment, ...), -1 the choice of meat and zero the choice of the option "neither/nor" see section before). As the reference category for the multinomial logit model, the meat option was chosen. For the scales, the z-standardised scores entered the reported model. Therefore, data were modelled according to the following expression:

$$
\begin{aligned}
\mathbf{x}^{\prime} \beta= & \text { buy.freq. organic/free range } * \beta_{1} \\
& + \text { healthier } * \beta_{2} \\
& + \text { more tasty } * \beta_{3} \\
& + \text { better for the environment } * \beta_{4} \\
& + \text { better for animal welfare } * \beta_{5} \\
& + \text { FNS } * \beta_{6} \\
& + \text { MAQ } * \beta_{7} \\
& + \text { buy.freq. plant-based alternatives } * \beta_{8} \\
& + \text { constant }
\end{aligned}
$$

The above mentioned parameters are estimated for meathybrid $\left(Y_{1}\right)$ and the "none"option $\left(Y_{2}\right)$, whereas meat $\left(Y_{3}\right)$ was set as reference category in the estimation. From the estimation results odds ratios are calculated. The odds ratios in logistic regression can be interpreted as the effect of a one unit of change in $X$ in the predicted odds ratio with the other variables in the model being held constant.

In this study for estimating the specified model, the software R [56] and the package mlogit [57] were used. For visualisation of odds ratios from the estimated model, the package sjplot [58] was applied.

\section{Results and Discussion}

\subsection{Preferred Buying Location and Buying Frequency of Organic Respectively Free Range Meat}

At the beginning of the questionnaire, the participants had to indicate where they buy most of their meat products. The classical retailer took the first position $(48.6 \%)$ followed by discount shops (38.6\%). Butcheries were in third position (10.2\%). All other options were only of minor importance (see Table 1 ).

Furthermore, the respondents were asked for their buying frequency of organic meat respectively meat from free-range production. Approximately $22 \%$ of the participants indicated to buy such products often $(18.2 \%$ ) or always $(4.2 \%)$ (see Table 2$)$. In 2019, a survey was conducted by Kitchen Stories [59], investigating the purchasing behaviour 
towards organic food in Germany. In the mentioned study, somewhat higher values were found with $13.2 \%$ bought mostly organic products, while, for $18.6 \%$ of the respondents, organic food made up more than half of the shopping cart. Contrarily, De Boer et al. [2] found much lower values for the Netherlands, where only $8 \%$ of the respondents indicated buying such products often or always.

Table 1. Preferred buying location of meat/meat products.

\begin{tabular}{lr}
\hline Location & \% \\
\hline retailer & 48.6 \\
discount & 38.6 \\
butcher & 10.2 \\
market & 1.2 \\
online & 0.6 \\
others & 0.6 \\
farm & 0.2 \\
\hline
\end{tabular}

Table 2. Buying frequency organic/free-range meat.

\begin{tabular}{lr}
\hline & $\%$ \\
\hline never & 15.4 \\
sometimes & 62.2 \\
often & 18.2 \\
always & 4.2 \\
\hline
\end{tabular}

\subsection{Meat Attachement Questionnaire (MAQ) and Food Neophobia Scale (FNS)}

Because of the confirmatory factor analysis, the item "I would feel fine with a meatless diet" was deleted from the MAQ-scale, because, in the four-factor solution, this item has a similar loading on different factors and its deletion increased the calculated indices. The reliability analysis for the global MAQ showed a high internal consistency with a standardized Cronbach $\alpha$ of 0.86. The Comparative Fit Index (CFI = 0.962), the Tucker-Lewis Index (TLI = 0.952), and the Root Mean Square Error of Approximation (RMSEA = 0.060) showed acceptable values. In comparison to Graca et al. [20], we received higher values for the non-reversed items and lower values for the reversed item, which might be due to the fact that vegans and vegetarians were not part of this study (see Table 3). On average, the respondents agree to all of the statements. The highest means received the statements "I love meals with meat" (3.94) and the reverse-coded item "Meat reminds me of diseases". This evaluation demonstrates that most of the respondents consider meat not as an unhealthy product but as an essential part of their diet. For use in the regression analysis, the individual scores, which is the z-standardised mean value across the 14 items, were calculated. The higher the MAQ-score, the higher indiviudals' attachment to meat.

After deleting two items from the original FNS-list due to low item-correlations in the reliability analysis and one item due to the confirmatory factor analysis, FNS showed an acceptable internal consistency with a standardized Cronbach $\alpha$ of 0.76 (see Table 4). The confirmatory factor analysis (two-factor-solution) produced acceptable values for the three considered indices (CFI $=0.961 \mathrm{TLI}=0.937$ and RMSEA $=0.074)$. The deleted items were: "I do not trust new (different or innovative) food", "If I don't know what a food is, I won't try it", "I am very particular about the food I eat". For use in the regression analysis, the individual scores, which is the $\mathrm{z}$-standardised mean value across the seven items, were calculated. The higher the FNS-score, the higher indiviudals' food neophobia. 
Table 3. Meat attachment questionnaire scale (MAQ).

\begin{tabular}{llll}
\hline Statement & std. $\alpha$ & $\bar{x}$ & $\sigma$ \\
\hline I love meals with meat. & 0.84 & 3.94 & 1.00 \\
To eat meat is one of the good pleasures in life. & 0.85 & 3.38 & 1.08 \\
I'm a big fan of meat. & 0.84 & 3.58 & 1.07 \\
A good steak is without comparison. & 0.84 & 3.76 & 1.12 \\
By eating meat I'm reminded of the death and suffering of animals. (r) & 0.86 & 3.50 & 1.19 \\
To eat meat is disrespectful towards life and the environment. (r) & 0.86 & 3.30 & 1.19 \\
Meat reminds me of diseases. (r) & 0.86 & 3.86 & 1.18 \\
To eat meat is an unquestionable right of every person. & 0.86 & 3.57 & 1.12 \\
According to our position in the food chain, we have the right to eat meat. & 0.86 & 3.68 & 1.13 \\
Eating meat is a natural and indisputable practice. & 0.85 & 3.75 & 0.98 \\
I don't picture myself without eating meat regularly. & 0.85 & 3.56 & 1.14 \\
If I couldn't eat meat I would feel weak. & 0.85 & 3.12 & 1.19 \\
I would feel fine with a meatless diet. (r) & & 3.32 & 1.14 \\
If I was forced to stop eating meat, I would feel sad. & 0.85 & 3.38 & 1.15 \\
Meat is irreplaceable in my diet. & 0.84 & 3.43 & 1.11 \\
\hline
\end{tabular}

Table 4. Food neophobia scale (FNS).

\begin{tabular}{llll}
\hline Statement & std. $\alpha$ & $\bar{x}$ & $\sigma$ \\
\hline I am constantly sampling new and different food. (r) & 0.74 & 2.75 & 1.17 \\
I do not trust new (different or innovative) food. & & 2.93 & 1.11 \\
If I don't know what a food is, I won't try it. & & 3.85 & 1.00 \\
I prefer food from different cultures. (r) & 0.72 & 2.59 & 1.07 \\
I am reluctant to eat foreign food that I see for the first time. & 0.74 & 2.96 & 1.21 \\
If I go to a buffet, meetings or parties, I'll eat new food. (r) & 0.73 & 2.32 & 1.09 \\
I'm afraid to eat food that I did not eat before. & 0.73 & 2.49 & 1.23 \\
I am very particular about the food I eat. & & 3.06 & 1.13 \\
I will eat almost anything. (r) & 0.76 & 2.32 & 1.10 \\
I like to try new ethnic restaurants. (r) & 0.70 & 2.36 & 1.10 \\
\hline
\end{tabular}

\subsection{Consumption of Substitutes}

A high proportion of $54.2 \%$ of the respondents stated to choose consciously meatless alternatives (see Table 5). Regarding the ranking task, the option fish was selected by $48.3 \%$ of this segment, followed by cheese $(47.6 \%)$, eggs $(41.7 \%)$, pasta $(39.5 \%)$, and salad $(35.4 \%)$, as the most preferred substitutes (see Table 5). It is to highlight that the top three on the list are non-vegan alternatives whereas vegan alternatives like protein-rich lentils, tofu, or seitan were only of minor importance. The findings correspond with the results of De Boer et al. [2], which found a similar ranking (fish, eggs, cheese, etc.) with lentils, nuts, seitan, tempeh. and tofu as less often mentioned items $(<20 \%)$. It is worth highlighting that, from a sustainability perspective, the first ranked products offer not much advantage when compared with meat [14].

Concerning the consumption of meat substitutes as e.g., veggie burgers, only $4.0 \%$ indicated consuming such products frequently, whereas $14.4 \%$ stated to do so at least sometimes (see Table 6). The figures are somewhat lower, as found by De Boer et al. [2] for the Netherlands, where $8 \%$ of the respondents reported to frequently buy such products. In contrast, similar values as in Germany were observed by Siegrist and Hartmann [35] for Switzerland, where approximately $23.5 \%$ were stated to consume substitutes. 
Table 5. Substitution of meat and ranking list consumed meat alternatives.

\begin{tabular}{|c|c|c|}
\hline & \multicolumn{2}{|c|}{ Substitution of Meat } \\
\hline & yes & no \\
\hline & $54.2 \%$ & $45.8 \%$ \\
\hline & \multicolumn{2}{|c|}{ Ranking list } \\
\hline $\mathrm{nr}$ & product & $\%$ \\
\hline 1 & Fish & 48.3 \\
\hline 2 & Cheese & 47.6 \\
\hline 3 & $\operatorname{Egg}(\mathrm{s})$ & 41.7 \\
\hline 4 & Pasta & 39.5 \\
\hline 5 & Salad & 35.4 \\
\hline 6 & Other legumes & 15.1 \\
\hline 7 & Lentils & 9.6 \\
\hline 8 & Nuts & 8.9 \\
\hline 9 & Tofu & 6.3 \\
\hline 10 & Seitan & 1.8 \\
\hline 11 & Other & 1.1 \\
\hline 12 & Tempeh & 0.4 \\
\hline
\end{tabular}

Table 6. Frequency of consumption of meat alternatives, such as veggie burgers.

\begin{tabular}{lr}
\hline & \% \\
\hline never & 45.6 \\
tried it once & 16.0 \\
rarely & 20.0 \\
sometimes & 14.4 \\
frequently & 4.0 \\
\hline
\end{tabular}

\subsection{Comparison Meat vs. Meathybrid}

In the comparison task, concerning the parameters health, environment, and animal welfare, the meathybrid was evaluated to be much better then the meat option (see Table 7). It is to highlight that, contrary to the reported literature for the perception of meat substitutes, meathybrids are, on average, seen as healthier than meat. This outcome is quite surprising against the background that only respondents that consume meat were interviewed. Although in meathybrids only a fraction of the meat is replaced by plantbased proteins, the majority of the respondents evaluate these products to be better for the environment and even better for animal welfare. In relation to the taste, meat significantly outperformed the hybrid alternative. Only a small segment of $16.8 \%$ expect a better taste for meathybrids as compared to meat. In drawing lessons from the recent history of dietary changes, Wansink [60] noted that, in its most basic form, an acceptable food must taste good, familiar, and must look, taste, and feel as expected. Therefore, low taste expectations regarding meathybrids represent a barrier for the consumption of this products. This is reflected by the fact that, in the choice task, only $27.4 \%$ indicated choosing the meathybrid in the direct comparison, whereas about $60 \%$ voted for the meat option. That is, despite the good evaluation of the hybrids for the other reported parameters (health, environmental perception, animal welfare), taste dominates when it comes to final choice decision.

Table 7. Comparison meat vs. hybrid.

\begin{tabular}{llll}
\hline & Meat & Neither/Nor & Hybrid \\
\hline healthier & $31.0 \%$ & $27.2 \%$ & $41.8 \%$ \\
tastier & $62.4 \%$ & $20.8 \%$ & $16.8 \%$ \\
better for environment & $15.8 \%$ & $31.0 \%$ & $53.2 \%$ \\
better for animal welfare & $15.6 \%$ & $26.8 \%$ & $57.6 \%$ \\
I would choose ... & $59.4 \%$ & $13.2 \%$ & $27.4 \%$ \\
\hline
\end{tabular}




\subsection{Multinomial Logit Regression Analysis}

The regression model was checked for indications of multicollinearity by examining the condition index. Values that are greater than 30 are typically considered to be problematic [61]. No violations of limits were found.

It is to highlight that the constant for the meatyhbrid revealed a negative and significant value $\left(-1.470^{* * *}\right)$. That is, the analysed sample has a much higher preference for the reference category meat in comparison to the meathybrid alternative and to the "neither/nor"-option. This outcome was expected due to the chosen sample of meat eaters. The MAQ-results demonstrate that, the more meat attached the interviewees, the higher the probability not to choose the hybrid option $\left(-0.837^{* * *}\right)$ (see Table 8 ). This finding is in line with Graca et al. [62], who found significant negative associations from meat attachment to meat substitution.

Furthermore, the extent of food neophobia $\left(-0.254^{*}\right)$ exerted an significant negative effect on the choice of hybrids. Thus, it can be hypothesized that meathybrids are perceived to a certain degree as 'exotic', 'neo', or 'artificial', as, for example, burgers based on insects or cultured meat, where FNS is likewise a big barrier. This corresponds to the results of Hoek et al. [52], which identified high food neophobia as strong barrier for the consumption of meat substitutes. Product familiarity, as recorded via the buying frequency of plant-based meat alternatives, can be seen as counterpart to the food neophobia construct. In this study, with increasing buying frequency of plant-based meat alternatives, like, e.g., veggie burgers, likewise the choice probability of the hybrid option increased $\left(0.292^{* *}\right)$. Nonetheless, the importance of this parameter is much lower than found by Hoek et al. [52], which stated that the most important determinant in the usage level of meat substitutes was familiarity with the product.

If respondents evaluated the hybrid as healthier, better for the environment, or better for animal welfare, then the choice probability for this option increased significantly. In this context, it is to highlight that the health perception had, by far, the strongest impact $\left(1.386^{* * *}\right)$, whereas the effect for the environmental and animal welfare perceptions were roughly only half of this size. Thus, the egoistic motive to improve or preserve the own health status seems to outperform altruistic motives, like animal welfare or environmental concerns, when it comes to choice for this new product category. Interestingly, for the buying frequency of organic meat respectively meat from free range production, no significant effect can be measured (0.038).

It is worth highlighting that the taste evaluation in the comparison task exerts a relatively strong effect on the choice of the hybrid option. That is, if the respondents perceived the taste of the meathybrid as better, the choice probability increases substantially.

In Figure 1 the odds ratios for the meathybrid coefficients from the multinomial logit regression are displayed. The fact that the alternative was a hybrid reduces the choice probability by $77 \%$ (odds ratio $=0.23$ ). Similar holds for the situation where the MAQ increases. Due to the fact that the MAQ is z-transformed, an increase of approximately one standard deviation leads to a reduction in the choice probability of $57 \%$. On the other hand, the choice probability increases by the factor 4 (odds ratio $=4.00$ ) if the consumer perceives the meathybrid as healthier. Therefore, the health perception nearly compensates the existing difference in preference of the alternatives. Likewise, a better assumed/expected taste of the meathybrid substantially increases the preference for this alternative by the factor 3.62. In the situation that the hybrid is perceived as better for the environment, the choice probability doubles. 
Table 8. Multinomial logit regression-results.

\begin{tabular}{lcc}
\hline & Hybrid & Neiter/Nor \\
& $(\mathbf{1})$ & $(\mathbf{2})$ \\
\hline buy. freq. organic/free range & -0.038 & $-0.328^{* *}$ \\
healthier & $(0.141)$ & $(0.166)$ \\
& $1.386^{* * *}$ & $0.533^{* *}$ \\
more tasty & $(0.213)$ & $(0.210)$ \\
& $1.289^{* * *}$ & $1.211^{* * *}$ \\
better for environment & $(0.205)$ & $(0.201)$ \\
& $0.700^{* * *}$ & 0.102 \\
better for animal welfare & $(0.223)$ & $(0.225)$ \\
& $0.498^{* *}$ & $-0.430^{*}$ \\
Food Neophobia Scale (FNS) & $(0.250)$ & $(0.224)$ \\
& $-0.254^{*}$ & -0.169 \\
Meat Attachement (MAQ) & $(0.149)$ & $(0.169)$ \\
buy. freq. plant-based alt. & $-0.837^{* * *}$ & -0.241 \\
Constant & $(0.168)$ & $(0.171)$ \\
& $0.292^{* *}$ & -0.062 \\
& $(0.142)$ & $(0.170)$ \\
Akaike Inf. Crit. & $-1.470^{* * *}$ & $-0.950^{* * *}$ \\
\hline
\end{tabular}

Significance levels: $^{*} p<0.1$; $^{* *} p<0.05$; $^{* * *} p<0.01$.

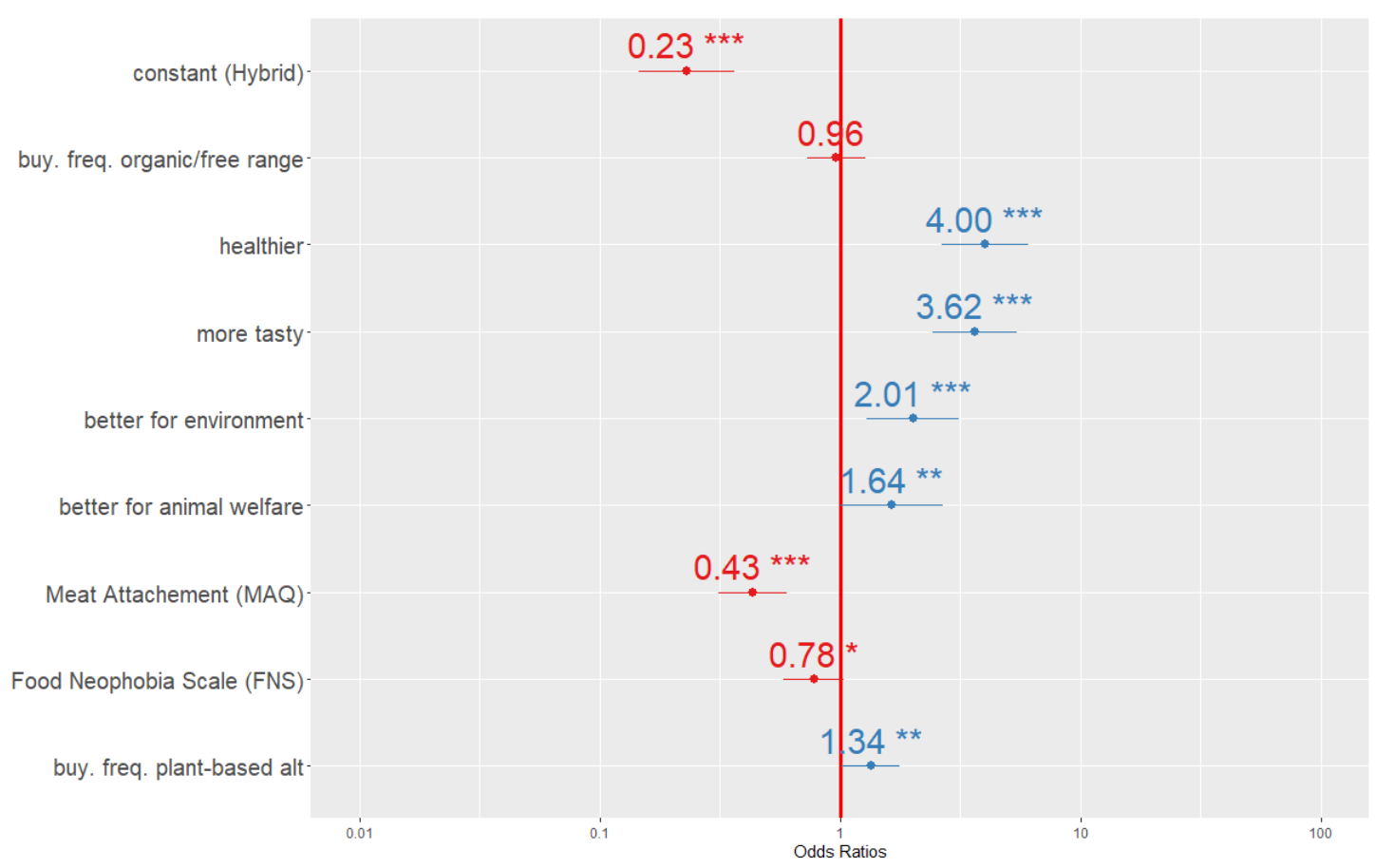

Figure 1. Odds ratios-estimation results meathybrid.

\section{Conclusions}

The results show that more than fifty percent of consumers substitute meat at least occasionally. Thus, approximately half of the respondents reveal an eligible consumption behaviour in respect to sustainability and healthiness at least sometimes. However, most of the consumed meat alternatives have an animal origin (dairy products, fish, eggs), which, like meat production, comes along with an environmental burden. In this context, it is to highlight that the findings of this study demonstrate that at least a substantial amount of consumers is open-minded to the "meathybrid" concept. Even a higher share believes that 
this new alternative is healthier, better for the environment and the animals in comparison to meat. Thus, there is chance that hybrids could serve as a low threshold option for a transition in the direction towards a more sustainable diet.

Nonetheless, on the road-map of this transition, some major problems and issues have to be tackled. This study and other research $[52,63]$ suggest that the current meathybrids and meat replacers are relatively unfamiliar and that their image in relation to the expected taste is quite mixed. While meathybrids have a plant-based protein share, they are not necessarily optimal from an environmental perspective, because their processing stage can require a considerable input of energy and they often contain a high share egg protein $[11,64]$. Although technological developments have led to improvements in the quality of meathybrids in recent years, it is still important to develop improved meathybrids and meat substitutes, which are significantly better and superior when compared to meat in several ways, such as taste, texture, and environmental performance, with a lower input of energy and egg white $[65,66]$.

Despite technological challenges, there are also socio-cultural challenges. As shown, meat attachment, as a psychological construct, represents a barrier for diet change and transition. Future research should address this topic in more detail, and analyse how to overcome this attitude. Similar holds for the neophobia construct. In order to increase consumer knowledge and awareness, and thus familiarity, "superior" meathybrids could be introduced in public canteens (e.g., kindergarten, school, universities).

Supplementary Materials: The following are available online at https:/ / www.mdpi.com/2071-105 0/13/2/650/s1.

Author Contributions: Conceptualization, S.S., N.T., J.W., G.V.R. and V.H.; methodology, A.P., S.H. and U.E.; formal analysis, A.P., S.H.; writing-original draft preparation, A.P., K.B. and M.-C.B.; writing-review and editing, A.P., U.E. and S.B.; visualization, A.P.; project administration, M.C.B.; funding acquisition, N.T. All authors have read and agreed to the published version of the manuscript.

Funding: This IGF Project of the FEI is/was supported via AiF within the programme for promoting the Industrial Collective Research (IGF) of the German Ministry of Economic Affairs and Energy (BMWi), based on a resolution of the German Parliament. Project AiF 196 EN https://https: / /www. fei-bonn.de/gefoerderte-projekte/projektdatenbank/cornet-aif-196-en.projekt.

Institutional Review Board Statement: Not applicable.

Informed Consent Statement: Informed consent was obtained from all subjects involved in the study.

Data Availability Statement: The data presented in this study are available on request from the corresponding author. The data will be made publicly to a later stage.

Conflicts of Interest: The authors declare no conflict of interest. 


\section{Appendix A}

Table A1. Sample.

\begin{tabular}{|c|c|c|c|}
\hline Attribute & Characteristics & $\mathbf{n}$ & $\%$ \\
\hline \multirow[t]{2}{*}{ gender } & male & 245 & 49.0 \\
\hline & female & 255 & 51.0 \\
\hline \multirow{16}{*}{$\begin{array}{l}\text { federal } \\
\text { state }\end{array}$} & Baden-Württemberg & 66 & 13.2 \\
\hline & Bavaria & 75 & 15.0 \\
\hline & Berlin & 22 & 4.4 \\
\hline & Brandenburg & 15 & 3.0 \\
\hline & Bremen & 5 & 1.0 \\
\hline & Hamburg & 10 & 2.0 \\
\hline & Hesse & 37 & 7.4 \\
\hline & Mecklenburg-Vorpommern & 10 & 2.0 \\
\hline & Lower Saxony & 50 & 10.0 \\
\hline & North Rhine-Westphalia & 114 & 22.8 \\
\hline & Rhineland-Palatinate & 20 & 4.0 \\
\hline & Saarland & 5 & 1.0 \\
\hline & Saxony & 26 & 5.2 \\
\hline & Saxony-Anhalt & 15 & 3.0 \\
\hline & Schleswig-Holstein & 15 & 3.0 \\
\hline & Thuringia & 15 & 3.0 \\
\hline \multirow[t]{6}{*}{ age } & $<25$ years & 65 & 13.0 \\
\hline & $25-34$ years & 66 & 13.2 \\
\hline & $35-44$ years & 99 & 19.8 \\
\hline & $45-54$ years & 84 & 16.8 \\
\hline & 55-64 years & 73 & 14.6 \\
\hline & $>64$ years & 113 & 22.6 \\
\hline \multirow[t]{7}{*}{ education } & no school qualifications & 2 & 0.4 \\
\hline & still at school & 4 & 0.8 \\
\hline & junior high diploma & 88 & 17.6 \\
\hline & high school diploma & 193 & 38.6 \\
\hline & university-entrance diploma & 105 & 21.0 \\
\hline & bachelor or master degree & 89 & 17.8 \\
\hline & other degree & 19 & 3.8 \\
\hline \multirow{10}{*}{$\begin{array}{l}\text { monthly net } \\
\text { income }\end{array}$} & no income & 26 & 5.2 \\
\hline & less than $500 €$ & 30 & 6.0 \\
\hline & $500 €$ up to $1000 €$ & 46 & 9.2 \\
\hline & $1000 €$ up to $1500 €$ & 95 & 19.0 \\
\hline & $1500 €$ up to $2000 €$ & 92 & 18.4 \\
\hline & $2000 €$ up to $2500 €$ & 69 & 13.8 \\
\hline & $2500 €$ up to $3000 €$ & 57 & 11.4 \\
\hline & $3000 €$ up to $3500 €$ & 27 & 5.4 \\
\hline & $3500 €$ up to $4000 €$ & 25 & 5.0 \\
\hline & $4000 €$ or more & 33 & 6.6 \\
\hline \multirow{7}{*}{$\begin{array}{l}\text { household } \\
\text { size }\end{array}$} & 1 & 121 & 24.2 \\
\hline & 2 & 207 & 41.4 \\
\hline & 3 & 92 & 18.4 \\
\hline & 4 & 55 & 11.0 \\
\hline & 5 & 20 & 4.0 \\
\hline & 6 & 4 & 0.8 \\
\hline & $>6$ & 1 & 0.2 \\
\hline
\end{tabular}

\section{Appendix B}

Logistic regression is the regression analysis to conduct when the dependent variable is nominal with more than two levels. It is used to model nominal outcome variables, in which the log odds of the outcomes are modeled as a linear combination of the predictor 
variables. The multinomial logistic model belongs to the family of generalized linear models and as mentioned is used when the response variable is a categorical variable [67]. Suppose that variable $Y_{i}$ represents the offered alternatives in a choice experiment (e.g., choice between meat and meathybrid), with $i=1, \ldots, n$ and $n$ is the number of possible product alternatives. In case $n$ equals 2 and $Y$ has outcomes $Y_{1}$ and $Y_{2}$. Both the counts of $Y_{1}$ and $Y_{2}$ follow a binomial distribution. The probability of occurrence of $Y_{1}$ is $\pi_{1}$ and that of $Y_{2}$ is $\pi_{2}$. Logistic regression relates probability $\pi_{1}$ to a set of predictors using the logit link function:

$$
\operatorname{logit}\left(\pi_{1}\right)=\ln \left(\frac{\pi_{1}}{\pi_{2}}\right)=\ln \left(\frac{\pi_{1}}{1-\pi_{1}}\right)=\mathbf{x}^{\prime} \beta
$$

where $\mathbf{x}$ is a vector of predictors (e.g., FNS, MAQ or buying frequency of organic meat), and $\beta$ is a vector of model coefficients that are typically estimated by maximum likelihood. Equation (A1) can be rewritten as:

$$
\left(\frac{\pi_{1}}{1-\pi_{1}}\right)=\exp \left(\mathbf{x}^{\prime} \beta\right)=\exp (\eta)
$$

The quotient in Equation (A2) is referred to as the odds. From Equation (A2) follows that:

$$
\pi_{1}=\frac{\exp (\eta)}{1+\exp (\eta)}
$$

The binomial logistic regression model is easily generalized to the multinomial case. If there are $n$ product alternatives there are also $n$ variables $Y_{1}, \ldots, Y_{n}$ with corresponding probabilities of occurrence $\pi_{1}, \ldots, \pi_{n}$. Analogous to binomial logistic regression the odds $\pi_{1} / \pi_{n}, \ldots, \pi_{n}-1 / \pi_{n}$ are modelled by means of $\exp \left(\eta_{1}\right), \ldots, \exp \left(\eta_{n-1}\right)$. From $\sum_{i=1}^{n} \pi_{i}=1$ it follows that:

$$
\pi_{1}=\frac{\exp \left(\eta_{i}\right)}{\exp \left(\eta_{1}\right)+\exp \left(\eta_{2}\right)+\ldots+\exp \left(\eta_{n}\right)}
$$

where $\exp \left(\eta_{n}\right)=0$. This model ensures that all probabilities are in the interval $[0,1]$ and that the probabilities sum to 1 .

\section{References}

1. Max Roser, H.R.; Ortiz-Ospina, E. World Population Growth. Our World Data 2013. Available online: https:/ / ourworldindata. org/world-population-growth (accessed on 11 January 2021)

2. De Boer, J.; Schösler, H.; Aiking, H. "Meatless days" or "less but better"? Exploring strategies to adapt Western meat consumption to health and sustainability challenges. Appetite 2014, 76, 120-128. [CrossRef] [PubMed]

3. Hallström, E.; Röös, E.; Börjesson, P. Sustainable meat consumption: A quantitative analysis of nutritional intake, greenhouse gas emissions and land use from a Swedish perspective. Food Policy 2014, 47, 81-90. [CrossRef]

4. Richi, E.B.; Baumer, B.; Conrad, B.; Darioli, R.; Schmid, A.; Keller, U. Health risks associated with meat consumption: A review of epidemiological studies. Int. J. Vitam. Nutr. Res. 2015, 85, 70-78. [CrossRef] [PubMed]

5. Kroeze, C.; Bouwman, L. The role of nitrogen in climate change. Curr. Opin. Environ. Sustain. 2011, 3, 279-280. [CrossRef]

6. De Vries, W.; Kros, J.; Reinds, G.J.; Butterbach-Bahl, K. Quantifying impacts of nitrogen use in European agriculture on global warming potential. Curr. Opin. Environ. Sustain. 2011, 3, 291-302 [CrossRef]

7. Erisman, J.W.; Galloway, J.; Seitzinger, S.; Bleeker, A.; Butterbach-Bahl, K. Reactive nitrogen in the environment and its effect on climate change. Curr. Opin. Environ. Sustain. 2011, 3, 281-290. [CrossRef]

8. Profeta, A.; Hamm, U. Do consumers care about local feedstuffs in local food? Results from a German consumer study. NJAS Wagening. J. Life Sci. 2019, 88, 21-30. [CrossRef]

9. de Vries, M.; de Boer, I.J.M. Comparing environmental impacts for livestock products: A review of life cycle assessments. Livest. Sci. 2010, 128, 1-11. [CrossRef]

10. Herrero, M.; Wirsenius, S.; Henderson, B.; Rigolot, C.; Thornton, P.; Havlík, P.; De Boer, I.; Gerber, P. Livestock and the Environment: What Have We Learned in the Past Decade? Annu. Rev. Environ. Resour. 2015, 40, 177-202. [CrossRef]

11. Aiking, H. Future protein supply. Trends Food Sci. Technol. 2011, 22, 112-120. [CrossRef]

12. Xue, L.; Prass, N.; Gollnow, S.; Davis, J.; Scherhaufer, S.; Östergren, K.; Cheng, S.; Liu, G. Efficiency and Carbon Footprint of the German Meat Supply Chain. Environ. Sci. Technol. 2019, 53, 5133-5142. [CrossRef] [PubMed]

13. Durlinger, B.; Koukouna, E.; Broekema, R.; Van Paassen, M.; Scholten, J. Agri-footprint 4.0. In Technical Report; Blonk Consultants: Gouda, The Netherlands, 2017. 
14. Schösler, H.; de Boer, J.; Boersema, J.J. Can we cut out the meat of the dish? Constructing consumer-oriented pathways towards meat substitution. Appetite 2012, 58, 39-47. [CrossRef] [PubMed]

15. Grandin, T. Welfare Problems in Cattle, Pigs, and Sheep that Persist Even Though Scientific Research Clearly Shows How to Prevent Them. Animals 2018, 8, 124. [CrossRef] [PubMed]

16. Dawkins, M. Animal Suffering, 1st ed.; Springer: Dordrecht, The Netherlands, 1980; p. 150. [CrossRef]

17. Sans, P.; Combris, P. World meat consumption patterns: An overview of the last fifty years (1961-2011). Meat Sci. 2015, 109, 106-111. [CrossRef] [PubMed]

18. Stoll-Kleemann, S.; Schmidt, U.J. Reducing meat consumption in developed and transition countries to counter climate change and biodiversity loss: A review of influence factors. Reg. Environ. Chang. 2017, 17, 1261-1277. [CrossRef]

19. Neville, M.; Tarrega, A.; Hewson, L.; Foster, T. Consumer-orientated development of hybrid beef burger and sausage analogues. Food Sci. Nutr. 2017, 5, 852-864. [CrossRef]

20. Graça, J.; Calheiros, M.M.; Oliveira, A. Attached to meat? (Un)Willingness and intentions to adopt a more plant-based diet. Appetite 2015, 95, 113-125. [CrossRef]

21. Hartmann, C.; Siegrist, M. Consumer perception and behaviour regarding sustainable protein consumption: A systematic review. Trends Food Sci. Technol. 2017, 61, 11-25. [CrossRef]

22. Tucker, C.A. The significance of sensory appeal for reduced meat consumption. Appetite 2014, 81, 168-179. doi:10.1016/j.appet.2014.06.022. [CrossRef]

23. Topcu, Y.; Uzundumlu, A.S.; Baran, D. How sensory and hedonic quality attributes affect fresh red meat consumption decision of Turkish consumers? Ital. J. Food Sci. 2015, 27, 53-62. [CrossRef]

24. Akwetey, W.Y.; Ellis, W.O.; Oduro, I.N. Using whole cowpea flour (WCPF) in frankfurter-type sausages. J. Anim. Prod. Adv. 2012, $2,450-455$

25. Zayas, J.; Lin, C. Effect of the Pretreatment of Corn Germ Protein on the Quality Characteristics of Frankfurters. J. Food Sci. 1989, 54, 1452-1456. [CrossRef]

26. Asgar, M.A.; Fazilah, A.; Huda, N.; Bhat, R.; Karim, A.A. Nonmeat protein alternatives as meat extenders and meat analogs. Compr. Rev. Food Sci. Food Safety 2010, 9, 513-529. [CrossRef]

27. Osen, R.; Toelstede, S.; Wild, F.; Eisner, P.; Schweiggert-Weisz, U. High moisture extrusion cooking of pea protein isolates: Raw material characteristics, extruder responses, and texture properties. J. Food Eng. 2014, 127, 67-74. [CrossRef]

28. Baune, V.M.C.; Baron, M.; Profeta, A.; Smetana, S.; Rohstoffes, B. Einfluss texturierter Pflanzenproteine auf Rohmassen hybrider Chicken Nuggets. Fleischwirtschaft 2020, 82-88. Available online: https:/ /www.genios.de/fachzeitschriften/artikel/FLW/2020 0715/einfluss-texturierter-pflanzenprote/20200715540766.html (accessed on 11 January 2021).

29. Godfray, H.C.J.; Aveyard, P.; Garnett, T.; Hall, J.W.; Key, T.J.; Lorimer, J.; Pierrehumbert, R.T.; Scarborough, P.; Springmann, M.; Jebb, S.A. Meat consumption, health, and the environment. Science 2018, 361. [CrossRef]

30. McAuliffe, G. A thematic review of life cycle assessment (LCA) applied to pig production. Environ. Impact Assess. Rev. 2015, 56, 12-22. [CrossRef]

31. Zhu, X.; van Ierland, E.C. Protein Chains and Environmental Pressures: A Comparison of Pork and Novel Protein Foods. Environ. Sci. 2004, 1, 254-276. [CrossRef]

32. Profeta, A. The Impact of Health Claims in Different Product Categories. J. Int. Food Agribus. Mark. 2019. doi:10.1080/08974438.2019.1599753. [CrossRef]

33. Macdiarmid, J.I.; Douglas, F.; Campbell, J. Eating like there's no tomorrow: Public awareness of the environmental impact of food and reluctance to eat less meat as part of a sustainable diet. Appetite 2016, 96, 487-493. [CrossRef]

34. Apostolidis, C.; McLeay, F. Should we stop meating like this? Reducing meat consumption through substitution. Food Policy 2016, 65, 74-89. [CrossRef]

35. Siegrist, M.; Hartmann, C. Impact of sustainability perception on consumption of organic meat and meat substitutes. Appetite 2019, 132, 196-202. [CrossRef] [PubMed]

36. Mullee, A.; Vermeire, L.; Vanaelst, B.; Mullie, P.; Deriemaeker, P.; Leenaert, T.; De Henauw, S.; Dunne, A.; Gunter, M.J.; Clarys, P.; Huybrechts, I. Vegetarianism and meat consumption: A comparison of attitudes and beliefs between vegetarian, semi-vegetarian, and omnivorous subjects in Belgium. Appetite 2017, 114, 299-305. [CrossRef] [PubMed]

37. De Backer, C.J.; Hudders, L. Meat morals: Relationship between meat consumption consumer attitudes towards human and animal welfare and moral behavior. Meat Sci. 2015, 99, 68-74. [CrossRef] [PubMed]

38. Bernstein, A.M.; Sun, Q.; Hu, F.B.; Stampfer, M.J.; Manson, J.E.; Willett, W.C. Major dietary protein sources and risk of coronary heart disease in women. Circulation 2010, 122, 876-883. [CrossRef] [PubMed]

39. Sinha, R.; Cross, A.J.; Graubard, B.I.; Leitzmann, M.F.; Schatzkin, A. Meat intake and mortality: A prospective study of over half a million people. Arch. Intern. Med. 2009, 169, 562-571. [CrossRef]

40. Hu, F.B. Plant-based foods and prevention of cardiovascular disease: An overview. Am. J. Clin. Nutr. 2003, 78, 544-551. [CrossRef]

41. Chalvon-Demersay, T.; Azzout-Marniche, D.; Arfsten, J.; Egli, L.; Gaudichon, C.; Karagounis, L.G.; Tomé, D. A systematic review of the effects of plant compared with animal protein sources on features of metabolic syndrome1-3. J. Nutr. 2017, 147, 281-292. [CrossRef] 
42. Young, V.R.; Pellett, P.L. Plant proteins in relation to human protein and amino acid nutrition. Am. J. Clin. Nutr. 1994, 59, 1203-1212. [CrossRef]

43. Verbeke, W. Profiling consumers who are ready to adopt insects as a meat substitute in a Western society. Food Qual. Prefer. 2015, 39, 147-155. [CrossRef]

44. Krarup, S.; Christensen, T.; Denver, S. Are Organic Consumers Healthier than Others? In Proceedings of the 16th IFOAM Organic World Congress, Modena, Italy, 16-20 June 2008.

45. Pliner, P.; Hobden, K. Development of a scale to measure the trait of food neophobia in humans. Appetite 1992, 19, 105-120. [CrossRef]

46. Capiola, A.; Raudenbush, B. The Effects of Food Neophobia and Food Neophilia on Diet and Metabolic Processing. Food Nutr. Sci. 2012, 03, 1397-1403. [CrossRef]

47. Damsbo-Svendsen, M.; Frøst, M.B.; Olsen, A. A review of instruments developed to measure food neophobia. Appetite 2017, 113, 358-367. [CrossRef] [PubMed]

48. Falciglia, G.A.; Couch, S.C.; Gribble, L.S.; Pabst, S.M.; Frank, R. Food neophobia in childhood affects dietary variety. J. Am. Diet. Assoc. 2000, 100, 1474-1482. [CrossRef]

49. Henriques, A.S.; King, S.C.; Meiselman, H.L. Consumer segmentation based on food neophobia and its application to product development. Food Qual. Prefer. 2009, 20, 83-91. [CrossRef]

50. Knaapila, A.; Tuorila, H.; Silventoinen, K.; Keskitalo, K.; Kallela, M.; Wessman, M.; Peltonen, L.; Cherkas, L.F.; Spector, T.D.; Perola, M. Food neophobia shows heritable variation in humans. Physiol. Behav. 2007, 91, 573-578. doi:10.1016/j.physbeh.2007.03.019. [CrossRef]

51. Vidigal, M.C.; Minim, V.P.; Simiqueli, A.A.; Souza, P.H.; Balbino, D.F.; Minim, L.A. Food technology neophobia and consumer attitudes toward foods produced by new and conventional technologies: A case study in Brazil. LWT Food Sci. Technol. 2015, 60, 832-840. [CrossRef]

52. Hoek, A.C.; Luning, P.A.; Weijzen, P.; Engels, W.; Kok, F.J.; de Graaf, C. Replacement of meat by meat substitutes. A survey on person- and product-related factors in consumer acceptance. Appetite 2011, 56, 662-673. [CrossRef]

53. Hartmann, C.; Shi, J.; Giusto, A.; Siegrist, M. The psychology of eating insects: A cross-cultural comparison between Germany and China. Food Qual. Prefer. 2015, 44, 148-156. [CrossRef]

54. Montanari, M. The Culture of Food (La Fame e L'abbondanza. Storia Dell'alimentazione in Europa); Blackwell: Oxford, UK, 1994.

55. Biesbroek, S.; Bas Bueno-De-Mesquita, H.; Peeters, P.H.; Monique Verschuren, W.M.; Van Der Schouw, Y.T.; Kramer, G.F.; Tyszler, M.; Temme, E.H. Reducing our environmental footprint and improving our health: Greenhouse gas emission and land use of usual diet and mortality in EPIC-NL: A prospective cohort study. Environ. Health Glob. Access Sci. Source 2014, 13, 1-9. [CrossRef]

56. R Core Team. R: A Language and Environment for Statistical Computing; R Core Team: Vienna, Austria, 2020. Available online: http:/ / www.R-project.org/ (accessed on 11 January 2021).

57. Croissant, Y. mlogit: Multinomial Logit Models. R Package Version 0.4-2. 2020. Available online: https://CRAN.R-project.org/ package $=$ mlogit (accessed on 11 January 2021).

58. Lüdecke, D. sjPlot: Data Visualization for Statistics in Social Science. R Package Version 2.8.4. 2020. Available online: https: / /CRAN.R-project.org/package=sjPlot (accessed on 11 January 2021).

59. Statista. Germany: Organic Food Purchase. 2019. Available online: https://www.statista.com/statistics/1085285/organic-foodpurchase-in-germany/ (accessed on 11 January 2021).

60. Wansink, B. Changing Eating Habits on the Home Front: Lost Lessons from World War II Research. J. Public Policy Mark. 2002, 21, 90-99. [CrossRef]

61. Cohen, J.; Cohen, P.; West, S.G.; Aiken, L.S. Applied Multiple Regression/Correlation Analysis for the Behavioral Sciences; Routledge: New York, NY, USA, 2013.

62. Graça, J.; Calheiros, M.M.; Oliveira, A. Situating moral disengagement: Motivated reasoning in meat consumption and substitution. Personal. Individ. Differ. 2016, 90, 353-364. [CrossRef]

63. Elzerman, J.E.; van Boekel, M.A.; Luning, P.A. Exploring meat substitutes: Consumer experiences and contextual factors. Br. Food J. 2013, 115, 700-710. [CrossRef]

64. Davis, J.; Sonesson, U.; Baumgartner, D.U.; Nemecek, T. Environmental impact of four meals with different protein sources: Case studies in Spain and Sweden. Food Res. Int. 2010, 43, 1874-1884. [CrossRef]

65. Aiking, H.; de Boer, J. Background, Aims and Scope. In Sustainable Protein Production and Consumption: Pigs or Peas? Aiking, H., de Boer, J., Vereijken, J., Eds.; Springer: Dordrecht, The Netherlands, 2006; pp. 1-21. [CrossRef]

66. Boland, M.J.; Rae, A.N.; Vereijken, J.M.; Meuwissen, M.P.; Fischer, A.R.; van Boekel, M.A.; Rutherfurd, S.M.; Gruppen, H.; Moughan, P.J.; Hendriks, W.H. The future supply of animal-derived protein for human consumption. Trends Food Sci. Technol. 2013, 29, 62-73. [CrossRef]

67. Long, J.S.; Freese, J. Regression Models for Categorical Dependent Variables Using Stata, 2nd ed.; Stata Press: College Station, TX, USA, 2001. 